\title{
Key Sectors of the Namibian Economy
}

\author{
Michael N. Humavindu • Jesper Stage
}

Received: 26 March 2012 / Accepted: 10 December 2012 / Published online: 4 January 2013 (C) 2013 M.N. Humavindu, J. Stage; licensee Springer. This is an Open Access article distributed under the terms of the Creative Commons Attribution License (http://creativecommons.org/licenses/by/2.0), which permits unrestricted use, distribution, and reproduction in any medium, provided the original work is properly cited.

\begin{abstract}
The present paper presents key sector research for the Namibian economy, based on input-output and Social Accounting Matrix (SAM) analyzes. The analyses were derived from a Namibian SAM for the 2004 period, using 28 economic sectors. We find that mining and government services are currently key sectors. Some manufacturing and services sectors have important linkages in terms of output effects, whilst for employment and income effects, the agriculture sector is paramount. The results obtained are useful for policy purposes in terms of identifying those sectors where interventions are likely to have the greatest impact on the Namibian economy.
\end{abstract}

JEL Classification $\mathrm{C} 67 \cdot \mathrm{L} 16 \cdot \mathrm{O} 21 \cdot \mathrm{O} 55$

\section{Introduction}

The purpose of this paper is to determine the key productive sectors for the Namibian economy. The principal concern with a key sector analysis is the identification of economic activities that exhibit the largest amount of interdependence with the rest of the economy. Such interdependence is usually measured through either backward or forward linkages. Backward linkages pertain to the dependence of a given economic activity on inputs produced from other activities, whilst forward linkages relate to a given economic sector's role in supplying inputs to other sectors.

M.N. Humavindu

Namibian Competition Commission, Windhoek, Namibia

M.N. Humavindu

Department of Economics, Umeå University, Umeå, Sweden

J. Stage $(\bowtie)$

Department of Social Sciences, Mid Sweden University, Sundsvall, 851 70, Sweden

e-mail: jesper.stage@miun.se 
The overall concern with the identification of key sectors is their usefulness in economic development strategy. Since key sectors have high backward and forward linkages with the rest of the economy, investment in these sectors is expected to enhance economic development prospects $[6,7,14]$.

Despite the usefulness of identifying key sectors, especially for development planning, key sector analysis has not been widely used in developing countries in recent years. Indeed, most recent studies have been in developed countries. Part of the reason for this low level of use is perhaps the considerable data requirements: even a basic key sector analysis requires an input-output table, which is only compiled every ten years or so (if at all) by most developing countries. In addition, more extensive analyzes such as the one presented here require employment data, which are often lacking in developing countries. Moreover, many developing countries are capital scarce and cannot easily support investment in key sectors even if such sectors are identified, making them less interesting from a policy perspective. However, key sector analysis remains a useful tool in those countries where the necessary data and the necessary funding are available. This study presents the first set of key sector analyzes for the Namibian economy.

Namibia is located in southern Africa. It has 2.1 million inhabitants and a gross domestic product (GDP) of approximately US\$12.5 billion, with per capita annual income registered at almost US\$6,000. It is classified as a lower-middle-income country $[2,17]$. Yet Namibia has one of the most unequal income distributions on the African continent, with a Gini coefficient of 0.63. Unemployment (estimated at $36.7 \%$ and $52 \%$ of the labor force in 2004 and 2008, respectively), poverty (56\% of the population live on less than US $\$ 2$ a day) and household food security are major challenges faced by the country. The Namibian economy is dualistic in character as it comprises a modern market sector based on capital-intensive industry and farming, producing most of the country's wealth, and a traditional subsistence farming sector.

The Namibian economy has a high degree of openness as the sum of exports and imports equates to more than $90 \%$ of GDP. Most raw material commodities are exported in unprocessed or semi-processed form, and many consumer goods are imported. Agriculture has a small contribution to GDP (around $5 \%$ ), but it employs about $30 \%$ of the total labor force. The largest part of the economic contribution from agriculture is from relatively large, commercial farms, but traditional subsistence farming remains crucial for supporting a large share of the population. About $70 \%$ of the population depend directly or indirectly on agriculture for their livelihood.

An important structural feature of the economy is the positive current account balance offset by a deficit on the capital and financial account. This reflects a chronic excess of savings over investment in the economy, thereby making Namibia a net exporter of capital. This means that, unlike the situation in many other developing countries, Namibia is not capital-scarce per se; if interesting investment opportunities are available, the country has funding available through its own domestic savings. This means that there is scope for policies to support the development of key sectors once these have been identified.

Namibia's new development policy frameworks (the Industrial Policy 2012 and the Fourth National Development Plan) are premised on a targeted sectoral approach. Unlike in the past, where the government attempted to develop all sectors, sector iden- 
tification and selection is now paramount. The sectors selected for the new growth strategy are manufacturing, transport, logistics and mineral processing. These are perceived to be sectors in which the country has a comparative advantage as well as growth potential. The selection of sectors for development also has a direct bearing on the deployment or direction of flow of instruments such as economic incentives as well as government research and development (R\&D). The country is also busy finalizing an Investment Bill that aims to help attract both foreign and domestic investment in key economic sectors. However, these sectors were mainly singled out as important for economic development based on consultations with stakeholders; no major assessment has been undertaken thus far in terms of a key sector analysis. Thus, an analytical exercise in identifying key sectors for the Namibian economy could help ensure that the new development approach to be adopted is grounded in economic reality.

\section{Methodology}

Key sector analysis of linkages in the economy began in the late 1950s, with seminal contributions by Nørregaard Rasmussen [16], Chenery and Watanabe [3], Hirschman [7], Augustinovics [1], Laumas [9-11], and Lenzen [12], among others. By way of an input-output table, backward linkages can be identified using a standard Leontief inverse [13] while forward linkages can be identified using a Ghosh inverse [5] or, alternatively, using the Leontief inverse as well. There is some debate among practitioners about which approach to use for forward linkages (see e.g. [4, 12, 18-20]). Lenzen [12] provides a useful overview of the pros and cons of the various approaches; we follow the approach that Lenzen actually uses in that paper for his own analysis, but note that his discussion can also be interpreted in favor of using other approaches.

In this study, we use a 28-sector input-output table developed from a recent social accounting matrix (SAM; see the discussion in Sect. 3, "Data", below). We use the $\mathbf{Z}$ matrix, showing those monetary flows between sectors that are considered endogenous to the model, to determine the Leontief matrix of input coefficients $\mathbf{A}$, given by $A_{i j}=Z_{i j} / X_{i}$, where $X_{i}$ is the total expenditure of sector $i, Z_{i j}$ is its spending on inputs from sector $j$, and $A_{i j}$ is spending on inputs from sector $j$ as a share of its overall expenditure.

We then determine the Leontief inverse $\mathbf{B}=[\mathbf{I}-\mathbf{A}]^{-1}$, which gives the backward and forward linkages from different sectors in the economy ( $\mathbf{I}$ is the identity matrix). The average backward multiplier of sector $j$ is given by $B . j=\sum_{i} b_{i j} / n$, where $n$ is the number of sectors. We normalize the backward multipliers by dividing the multiplier of each sector $j$ by the average multiplier for all sectors in the economy, $\bar{B}=\sum_{i, j} b_{i j} / n^{2}$, in order to get $B_{\cdot j}^{N}=B_{\cdot j} / \bar{B}$. In similar fashion, we calculate average forward multipliers as $B_{i} .=\sum_{j} b_{i j} / n$ and normalized forward multipliers as $B_{i}^{N}=B_{i \cdot} / \bar{B}$. Sectors with $B_{\cdot j}^{N}>1$ have higher-than-average backward linkages, and sectors with $B_{i}^{N}$. $>1$ have higher-than-average forward linkages. Sectors for which both these indicators are greater than 1 are referred to as key sectors: they have higherthan-average linkages both backward and forward, and thus have greater effects on the rest of the economy than most other sectors. 
Table 1 Identification of key sectors

\begin{tabular}{|c|c|c|c|c|}
\hline & & \multicolumn{2}{|c|}{$\begin{array}{l}\text { Strong forward linkages } \\
B_{i .}^{N}>1\end{array}$} & \multirow{2}{*}{$\begin{array}{l}\text { Limited forward } \\
\text { linkages } \\
B_{i \cdot}^{N}<1\end{array}$} \\
\hline & & $\begin{array}{l}\text { Dispersed forward } \\
\text { linkages } \\
V_{i}^{N}<1\end{array}$ & $\begin{array}{l}\text { Concentrated } \\
\text { forward linkages } \\
V_{i}^{N}>1\end{array}$ & \\
\hline \multirow[t]{2}{*}{$\begin{array}{l}\text { Strong backward } \\
\text { linkages } \\
B_{\cdot j}^{N}>1\end{array}$} & $\begin{array}{l}\text { Dispersed backward } \\
\text { linkages } \\
V_{\cdot j}^{N}<1\end{array}$ & $\begin{array}{l}\text { Key sectors with } \\
\text { widely dispersed } \\
\text { effects in the } \\
\text { economy }\end{array}$ & $\begin{array}{l}\text { Key sectors but with } \\
\text { forward linkages } \\
\text { concentrated }\end{array}$ & $\begin{array}{l}\text { Sectors with strong, } \\
\text { widely dispersed } \\
\text { backward linkages } \\
\text { but with weak } \\
\text { forward linkages }\end{array}$ \\
\hline & $\begin{array}{l}\text { Concentrated } \\
\text { backward linkages } \\
V_{\cdot j}^{N}>1\end{array}$ & $\begin{array}{l}\text { Key sectors but with } \\
\text { backward linkages } \\
\text { concentrated }\end{array}$ & $\begin{array}{l}\text { Key sectors without } \\
\text { widely dispersed } \\
\text { linkages }\end{array}$ & $\begin{array}{l}\text { Sectors with strong } \\
\text { but concentrated } \\
\text { backward linkages } \\
\text { and with weak } \\
\text { forward linkages }\end{array}$ \\
\hline \multicolumn{2}{|c|}{$\begin{array}{l}\text { Limited backward linkages } \\
B_{\cdot j}^{N}<1\end{array}$} & $\begin{array}{l}\text { Sectors with strong, } \\
\text { widely dispersed } \\
\text { forward linkages } \\
\text { but with weak } \\
\text { backward linkages }\end{array}$ & $\begin{array}{l}\text { Sectors with strong } \\
\text { but concentrated } \\
\text { forward linkages } \\
\text { and with weak } \\
\text { backward linkages }\end{array}$ & $\begin{array}{l}\text { Sectors with weak } \\
\text { linkages }\end{array}$ \\
\hline
\end{tabular}

However, it is also of interest to know whether or not these effects on the surrounding economy are widely dispersed among other sectors. If the effects are concentrated in one or a few sectors, there is a risk that bottlenecks in those sectors might reduce the impact of such effects, so that changes in the key sectors do not have the anticipated overall effect on the economy. Lenzen [12] discusses a case where a sector delivers a large share of some other sector's overall inputs and is, therefore, identified as a key sector, even though it has no linkages to other sectors in the economy. In order to assess the degree to which multiplier effects are dispersed among other sectors, one can calculate the backward and forward coefficients of variation, defined as $V_{\cdot j}=\sqrt{\frac{1}{n-1} \sum_{i}\left(b_{i j}-B_{\cdot j}\right)^{2}} / B_{. j}$ and $V_{i .}=\sqrt{\frac{1}{n-1} \sum_{j}\left(b_{i j}-B_{i} .\right)^{2}} / B_{i}$. These measure the degrees of sectoral skewness in input procurement and output delivery, respectively; the lower these coefficients are for a specific sector, the more evenly that sector's input purchases and output sales are dispersed among the different sectors of the economy. We can normalize these coefficients by dividing by the economy-wide averages and calculating $V_{\cdot j}^{N}=n V_{\cdot j} / \sum_{k} V_{\cdot k}$ and $V_{i \cdot}^{N}=n V_{i} \cdot / \sum_{k} V_{k} .$. If a sector has normalized coefficients that are lower than 1, it means that its backward and forward linkages, respectively, are more widely dispersed in the economy than those that pertain on average. High values, on the other hand, indicate that the sector interacts with only a few other sectors in the economy.

Thus, key sectors with widely dispersed effects are those with higher-than-average forward and backward linkages which are also dispersed more widely than average. Rueda-Cantuche et al. [21] provide a useful means of visualizing the different possible outcomes from a key sector analysis (Table 1). The upper left corner of Table 1 contains key sectors with widely dispersed backward and forward linkages throughout the rest of the economy. Moving downward in the table, we find sectors with 
less widely dispersed backward linkage effects on the rest of the economy and, at the bottom, sectors with no or limited overall backward impacts. Similarly, moving to the right, we first find sectors with less widely dispersed forward linkage effects, and then sectors with no (or limited) forward linkage effects. Notably, these definitions identify sectors with higher- or lower-than-average linkages and diffusion. In a highly trade-dependent economy such as Namibia's, where many of the linkages are to foreign trade rather than to domestic firms, even sectors with higher-than-average linkages may have relatively limited impacts compared with their counterparts in other, less trade-dependent countries.

In order to provide a picture of the current state of the economy, we also weight the coefficients in the Leontief inverse, based on their current shares $\sigma_{i}$ and $\delta_{j}$ of overall factor income and net final demand, respectively. This allows us to determine weighted backward and forward linkages $B_{\cdot j}^{\delta}=\sum_{i} b_{i j} \delta_{j}$ and $B_{i}^{\sigma}=\sum_{j} \sigma_{i} b_{i j}$. This weighting by sectoral size shows the current overall importance of different sectors in terms of providing inputs and/or outputs to other sectors, as opposed to the importance of a marginal change in a sector shown by the unweighted analysis.

Given the highly unequal distribution of income and high unemployment in Namibia, it is also of interest to examine whether the forward and backward linkage effects are different when one considers effects on employment or on labor income rather than on output per se. In order to study this, the sectors-in both the size-unweighted and -weighted cases-were weighted using two sets of coefficients $q_{i}$ showing the number of people employed per $\mathrm{N} \$$ million output and $\mathrm{N} \$$ million in labor income per $\mathrm{N} \$$ million output, respectively. The size-unweighted and size-weighted linkage measures are then given by $B_{\cdot j}^{q}=\sum_{i} q_{i} b_{i j} / n, B_{\cdot j}^{q \delta}=$ $\sum_{i} q_{i} b_{i j} \delta_{j} / n, B_{i .}^{q}=\sum_{j} b_{i j} q_{j} / n$ and $B_{i .}^{q \sigma}=\sum_{j} \sigma_{i} b_{i j} q_{j} / n$, respectively, with corresponding variance measures. In the size-unweighted case, the results show how much impact a marginal change in a sector would have on employment and on labor income, respectively. In the size-weighted case, the results show the current importance of each sector as a whole in terms of overall employment and labor income in the economy, respectively.

\section{Data}

The main source of data for this analysis was the Namibian SAM for 2004 [8] developed by researchers at the Namibian Economic Policy Research Unit (NEPRU). The Namibian SAM has 32 commodity sectors, including three dummy sectors for own real estate services, direct foreign purchases by Namibians, and direct domestic purchases by foreigners. There are 30 activity sectors, including two dummy accounts for own real estate services and for foreign tourism. As regards factor accounts, five exist for income to skilled labor, income to unskilled labor, mixed income to commercial agriculture, mixed income to communal agriculture, and capital income, respectively. There are nine institutions, comprising six household categories, non-profit organizations, enterprises, and government. And finally, there is a Savings/investment category and a Rest-of-world category. A list of the economic sectors in the Namibian SAM is provided in Table 2 . 
Table 2 Namibian economic sectors

\begin{tabular}{|c|c|c|c|}
\hline $\begin{array}{l}\text { Sectors in the input-output (IO) } \\
\text { table }\end{array}$ & $\begin{array}{l}\text { Activity sectors in } \\
\text { the social } \\
\text { accounting matrix } \\
\text { (SAM) }\end{array}$ & $\begin{array}{l}\text { Commodity sectors } \\
\text { in the SAM }\end{array}$ & Other sectors in the SAM \\
\hline $\begin{array}{l}\text { Commercial agriculture: } \\
\text { Cereal crops }\end{array}$ & Same as in the IO & Same as in the IO & \multirow{27}{*}{$\begin{array}{l}\text { Factors of production } \\
\text { Skilled labor } \\
\text { Unskilled labor } \\
\text { Mixed income- } \\
\text { Commercial agriculture } \\
\text { Mixed income- } \\
\text { Traditional agriculture } \\
\text { Gross operating surplus }\end{array}$} \\
\hline $\begin{array}{l}\text { Commercial agriculture: } \\
\text { Other crops }\end{array}$ & Same as in the IO & Same as in the IO & \\
\hline $\begin{array}{l}\text { Commercial agriculture: } \\
\text { Animal products }\end{array}$ & Same as in the IO & Same as in the IO & \\
\hline Traditional agriculture & Same as in the IO & Same as in the IO & \\
\hline Fishing & Same as in the IO & Same as in the IO & \\
\hline Mining & Same as in the IO & Same as in the IO & \\
\hline Meat processing & Same as in the IO & Same as in the IO & \\
\hline Fish processing & Same as in the IO & Same as in the IO & \\
\hline Grain milling & Same as in the IO & Same as in the IO & \\
\hline $\begin{array}{l}\text { Manufacture of beverages } \\
\text { and other food processing }\end{array}$ & Same as in the IO & Same as in the IO & \\
\hline Manufacture of textiles & Same as in the IO & Same as in the IO & \\
\hline $\begin{array}{l}\text { Manufacture of wood products } \\
\text { and furniture }\end{array}$ & Same as in the IO & Same as in the IO & \\
\hline $\begin{array}{l}\text { Manufacture of paper, } \\
\text { printing and publishing }\end{array}$ & Same as in the IO & Same as in the IO & \\
\hline $\begin{array}{l}\text { Manufacture of chemicals, } \\
\text { rubber and plastic }\end{array}$ & Same as in the IO & Same as in the IO & \\
\hline $\begin{array}{l}\text { Manufacture of other } \\
\text { non-metallic mineral } \\
\text { products }\end{array}$ & Same as in the IO & Same as in the IO & \\
\hline $\begin{array}{l}\text { Manufacture of basic } \\
\text { metals }\end{array}$ & Same as in the IO & Same as in the IO & \\
\hline $\begin{array}{l}\text { Manufacture of fabricated } \\
\text { metal products and machinery }\end{array}$ & Same as in the IO & Same as in the IO & \\
\hline Electricity & Same as in the IO & Same as in the IO & \\
\hline Water & Same as in the IO & Same as in the IO & \\
\hline Construction & Same as in the IO & Same as in the IO & \\
\hline Trade and repairs & Same as in the IO & Same as in the IO & \\
\hline Hotels and restaurants & Same as in the IO & Same as in the IO & \\
\hline Transport & Same as in the IO & Same as in the IO & \\
\hline Communication & Same as in the IO & Same as in the IO & \\
\hline Finance and insurance & Same as in the IO & Same as in the IO & \\
\hline $\begin{array}{l}\text { Market real estate and } \\
\text { business services }\end{array}$ & Same as in the IO & Same as in the IO & \\
\hline Other private social services & Same as in the IO & Same as in the IO & \\
\hline
\end{tabular}


Table 2 (Continued)

\begin{tabular}{|c|c|c|c|}
\hline $\begin{array}{l}\text { Sectors in the input-output (IO) } \\
\text { table }\end{array}$ & $\begin{array}{l}\text { Activity sectors in } \\
\text { the social } \\
\text { accounting matrix } \\
\text { (SAM) }\end{array}$ & $\begin{array}{l}\text { Commodity sectors } \\
\text { in the SAM }\end{array}$ & Other sectors in the SAM \\
\hline Government services & Same as in the IO & Same as in the IO & \\
\hline Own real estate (Dummy sector) & Same as in the IO & Same as in the IO & \\
\hline Foreign tourism (Dummy sector) & Same as in the IO & Same as in the IO & \\
\hline \multirow[t]{2}{*}{ Petroleum (Dummy sector) } & & Petroleum & \\
\hline & & $\begin{array}{l}\text { Purchases abroad } \\
\text { by residents } \\
\text { (Dummy sector) }\end{array}$ & \\
\hline
\end{tabular}

In the Namibian SAM, subsistence agriculture produces a composite ownconsumption food product, all of which is provided to people working in that sector. Thus, there are no forward linkages from this sector except through the food recipients' consumption, and there is no interaction with the other food sectors. This was identified as a limitation by the researchers compiling the SAM (ibid.). There is in fact also some commercial activity in the subsistence farming sector, but it is not captured very well by the current economic statistics. Apart from subsistence agriculture, informal economic activity is not included in the SAM.

The SAM was transformed into a symmetric, $31 \times 31$, activity-based input-output table with 28 domestic activity sectors and a dummy own real estate services sector, a dummy tourism sector, and a dummy sector for petroleum-based fuels as additional sectors. The transformation was done mathematically (see [22], for the methodology used) rather than by using sector-specific data.

For the employment multipliers, data from the 2004 labor force survey were used [15]. The Ministry of Labour reports on formal employment only, which means that the informal sector-again, apart from subsistence agriculture-is excluded, both in the SAM and in the labor force data. For the labor income multipliers, the income data from the SAM for unskilled and skilled labor were simply used, as well as the mixed income accruing to people active in traditional subsistence farming.

\section{Results and Discussion}

Tables 3 through 8 depict the results of the key sector analyzes described above. If one looks at the weighted analyzes, which show the current importance of various sectors in the Namibian economy, there are few surprises. Mining, Manufacturing of beverages and other food processing and Government services are crucial for overall output in the economy. Traditional (subsistence) agriculture and Government services are key sectors for both labor income and employment. Mining is a key sector for labor income, while Commercial agriculture: animal products is a key sector for employment. The results partly reflect how large all of these specific sectors are rather than the linkages that they create with the rest of the economy. 
Table 3 Key sector analysis in terms of output, not weighted by sector size

\begin{tabular}{|c|c|c|c|c|}
\hline Sector & $\begin{array}{l}\text { Backward } \\
\text { multiplier }\end{array}$ & $\begin{array}{l}\text { Backward } \\
\text { coefficient } \\
\text { of variation }\end{array}$ & $\begin{array}{l}\text { Forward } \\
\text { multiplier }\end{array}$ & $\begin{array}{l}\text { Forward } \\
\text { coefficient } \\
\text { of variation }\end{array}$ \\
\hline Commercial agriculture: Cereal crops & 0.8706 & 1.0599 & 0.8338 & 1.0533 \\
\hline Commercial agriculture: Other crops & 0.8413 & 1.1076 & 0.7051 & 1.1900 \\
\hline Commercial agriculture: Animal products & 0.8179 & 1.0987 & 0.9441 & 0.9710 \\
\hline Traditional agriculture & 0.7441 & 1.2133 & 0.5532 & 1.4737 \\
\hline Fishing & 0.9396 & 0.9656 & 0.7928 & 1.1043 \\
\hline Mining* & 1.0962 & 1.0140 & 1.0899 & 0.9441 \\
\hline Meat processing & 1.2438 & 0.8098 & 0.6347 & 1.2825 \\
\hline Fish processing & 1.0532 & 0.9147 & 0.5565 & 1.4676 \\
\hline Grain milling & 1.0457 & 0.9296 & 0.6990 & 1.1997 \\
\hline Manufacture of beverages and other food processing ${ }^{*}$ & 1.0830 & 1.0239 & 1.0467 & 0.9530 \\
\hline Manufacture of textiles & 0.8796 & 1.1908 & 0.8785 & 1.0693 \\
\hline Manufacture of wood products and furniture & 1.0380 & 0.9926 & 0.9527 & 0.9646 \\
\hline Manufacture of paper, printing and publishing ${ }^{*}$ & 1.1542 & 1.0886 & 1.4062 & 0.7862 \\
\hline Manufacture of chemicals, rubber and plastic ${ }^{*}$ & 1.1182 & 1.1277 & 1.9316 & 0.5722 \\
\hline Manufacture of other non-metallic mineral products & 1.1019 & 0.8611 & 0.7308 & 1.1654 \\
\hline Manufacture of basic metals & 1.2289 & 0.7660 & 0.5772 & 1.4113 \\
\hline Manufacture of fabricated metal products and machinery & 0.9789 & 0.9948 & 1.8319 & 0.4688 \\
\hline Electricity & 0.7908 & 1.3201 & 1.0075 & 0.9228 \\
\hline Water & 0.9207 & 1.2292 & 0.8213 & 1.2396 \\
\hline Construction & 1.2992 & 0.7131 & 0.6260 & 1.3023 \\
\hline Trade and repairs & 0.4572 & 0.4501 & 0.3764 & 0.2290 \\
\hline Hotels and restaurants & 1.0343 & 0.8767 & 0.8770 & 0.9950 \\
\hline Transport ${ }^{*}$ & 1.1233 & 0.8795 & 2.0323 & 0.4306 \\
\hline Communication & 0.9554 & 1.1380 & 1.3917 & 0.6833 \\
\hline Finance and insurance ${ }^{*}$ & 1.2883 & 0.9243 & 1.6721 & 0.6102 \\
\hline Market real estate and business services & 0.9042 & 1.1134 & 2.3884 & 0.3664 \\
\hline Other private social services & 1.0612 & 0.8628 & 0.7207 & 1.1346 \\
\hline Government services & 0.8161 & 1.1022 & 0.5804 & 1.4038 \\
\hline
\end{tabular}

* Key sectors are highlighted in bold

The unweighted analysis, which shows the effect that marginal changes in sectors would have on the overall economy, exhibits a more complicated picture. Not surprisingly, given the dualistic nature of the Namibian economy, the choice of metric is important for those sectors identified as key in the unweighted analysis. When a traditional output metric is used, a range of manufacturing sectors (and a few service sectors) are identified as key, with both backward and forward linkages, and many of the remaining manufacturing and service sectors are identified as having strong linkages in at least one direction. On the other hand, when labor income is used as a metric, the subsistence agriculture sector (where any change in production will, 
Table 4 Key sector analysis in terms of labor income, not weighted by sector size

\begin{tabular}{|c|c|c|c|c|}
\hline Sector & $\begin{array}{l}\text { Backward } \\
\text { multiplier }\end{array}$ & $\begin{array}{l}\text { Backward } \\
\text { coefficient } \\
\text { of variation }\end{array}$ & $\begin{array}{l}\text { Forward } \\
\text { multiplier }\end{array}$ & $\begin{array}{l}\text { Forward } \\
\text { coefficient } \\
\text { of variation }\end{array}$ \\
\hline Commercial agriculture: Cereal crops & 0.5637 & 0.9876 & 0.1959 & 0.9021 \\
\hline Commercial agriculture: Other crops & 0.6553 & 0.9817 & 0.4261 & 1.2346 \\
\hline Commercial agriculture: Animal products & 0.4650 & 0.8857 & 0.3779 & 0.9498 \\
\hline Traditional agriculture ${ }^{*}$ & 2.7414 & 1.6357 & 2.3457 & 1.6503 \\
\hline Fishing ${ }^{*}$ & 1.2385 & 1.2699 & 1.0070 & 1.3595 \\
\hline Mining & 0.9947 & 1.1247 & 0.8695 & 1.1102 \\
\hline Meat processing & 0.6759 & 0.6670 & 0.1634 & 1.1634 \\
\hline Fish processing & 1.1219 & 0.9518 & 0.4501 & 1.6452 \\
\hline Grain milling & 0.6514 & 0.8256 & 0.3049 & 1.1881 \\
\hline Manufacture of beverages and other food processing & 0.7286 & 0.8026 & 0.4916 & 0.6165 \\
\hline Manufacture of textiles & 0.5955 & 0.9134 & 0.5331 & 0.7805 \\
\hline Manufacture of wood products and furniture & 1.0698 & 0.9306 & 0.8651 & 0.9100 \\
\hline Manufacture of paper, printing and publishing ${ }^{*}$ & 1.3708 & 1.0902 & 1.7301 & 0.8848 \\
\hline Manufacture of chemicals, rubber and plastic & 0.8728 & 0.9269 & 1.4512 & 0.4969 \\
\hline Manufacture of other non-metallic mineral products & 1.0224 & 0.7876 & 0.4534 & 1.1775 \\
\hline Manufacture of basic metals & 1.0283 & 0.7827 & 0.3985 & 1.5769 \\
\hline Manufacture of fabricated metal products and machinery & 0.9280 & 1.0414 & 1.7488 & 0.4787 \\
\hline Electricity & 0.9304 & 1.4891 & 1.1905 & 1.0177 \\
\hline Water & 0.9276 & 1.3372 & 0.8591 & 1.2485 \\
\hline Construction & 0.8914 & 0.6208 & 0.2963 & 1.0943 \\
\hline Trade and repairs & 1.1747 & 1.3051 & 0.9902 & 1.3309 \\
\hline Hotels and restaurants & 0.7569 & 0.9159 & 0.4898 & 1.2105 \\
\hline Transport ${ }^{*}$ & 1.1674 & 1.0728 & 2.6019 & 0.7977 \\
\hline Communication & 0.9721 & 1.2245 & 1.9467 & 0.8795 \\
\hline Finance and insurance & 0.8571 & 0.7140 & 1.9054 & 0.8630 \\
\hline Market real estate and business services & 0.5878 & 0.9368 & 2.9077 & 0.7911 \\
\hline Other private social services & 1.8576 & 1.2998 & 1.4129 & 1.4757 \\
\hline Government services ${ }^{*}$ & 2.1877 & 1.5479 & 1.8195 & 1.6083 \\
\hline
\end{tabular}

${ }^{*}$ Key sectors are highlighted in bold

by definition, translate almost completely into a change in income and consumption for the people involved in the sector), fishing, and a few highly-paid, labor-intensive manufacturing and service sectors are the only ones identified as key sectors with large linkage effects on the economy. Finally, when employment is used as a metric, the low-wage, labor-intensive agricultural sectors come out as the only key sectors.

If one focuses on the output-oriented analysis, the results indicate several key sectors where increased activity could have important linkage effects on the economy. Of those identified as key sectors with widely dispersed effects, two are service sectors. One is transportation which is important for the economy not only because it 
Table 5 Key sector analysis in terms of employment, not weighted by sector size

\begin{tabular}{|c|c|c|c|c|}
\hline Sector & $\begin{array}{l}\text { Backward } \\
\text { multiplier }\end{array}$ & $\begin{array}{l}\text { Backward } \\
\text { coefficient } \\
\text { of variation }\end{array}$ & $\begin{array}{l}\text { Forward } \\
\text { multiplier }\end{array}$ & $\begin{array}{l}\text { Forward } \\
\text { coefficient } \\
\text { of variation }\end{array}$ \\
\hline Commercial agriculture: Cereal crops ${ }^{*}$ & 3.2270 & 1.4408 & 2.8142 & 1.5707 \\
\hline Commercial agriculture: Other crops ${ }^{*}$ & 3.0944 & 1.5084 & 2.7570 & 1.6132 \\
\hline Commercial agriculture: Animal products ${ }^{*}$ & 3.0798 & 1.4688 & 2.7692 & 1.5568 \\
\hline Traditional agriculture ${ }^{*}$ & 3.0264 & 1.4939 & 2.5800 & 1.6718 \\
\hline Fishing & 0.6739 & 1.0451 & 0.4292 & 1.4909 \\
\hline Mining & 0.3461 & 0.7048 & 0.2437 & 0.6628 \\
\hline Meat processing & 2.0295 & 1.2449 & 0.1635 & 1.1028 \\
\hline Fish processing & 0.4672 & 0.7652 & 0.1068 & 1.6427 \\
\hline Grain milling & 1.4342 & 1.1961 & 0.3719 & 1.0087 \\
\hline Manufacture of beverages and other food processing & 0.6414 & 0.7150 & 0.4343 & 0.6388 \\
\hline Manufacture of textiles & 0.4369 & 0.8062 & 0.4736 & 0.6431 \\
\hline Manufacture of wood products and furniture & 0.7928 & 0.8047 & 0.5346 & 0.6109 \\
\hline Manufacture of paper, printing and publishing & 0.6086 & 0.9439 & 1.0412 & 0.8876 \\
\hline Manufacture of chemicals, rubber and plastic & 0.6380 & 0.9526 & 1.4410 & 0.5253 \\
\hline Manufacture of other non-metallic mineral products & 0.5466 & 0.8230 & 0.2444 & 0.8374 \\
\hline Manufacture of basic metals & 0.4370 & 0.6266 & 0.1249 & 1.4031 \\
\hline Manufacture of fabricated metal products and machinery & 0.7191 & 1.0582 & 1.4880 & 0.5281 \\
\hline Electricity & 0.4347 & 1.2661 & 0.7141 & 0.7971 \\
\hline Water & 0.5030 & 1.1890 & 0.5693 & 1.0186 \\
\hline Construction & 0.8525 & 0.8577 & 0.4596 & 1.3932 \\
\hline Trade and repairs & 0.8987 & 1.3361 & 0.9173 & 1.2477 \\
\hline Hotels and restaurants & 1.0384 & 1.0394 & 0.7331 & 1.3966 \\
\hline Transport & 0.6175 & 0.8208 & 2.2011 & 0.7732 \\
\hline Communication & 0.4944 & 1.0095 & 1.5338 & 0.8519 \\
\hline Finance and insurance & 0.6344 & 0.8503 & 1.7314 & 0.8413 \\
\hline Market real estate and business services & 0.3843 & 0.8830 & 2.4098 & 0.8247 \\
\hline Other private social services & 0.7958 & 1.0144 & 0.5749 & 1.3212 \\
\hline Government services & 0.5439 & 1.1627 & 0.3851 & 1.5680 \\
\hline
\end{tabular}

${ }^{*}$ Key sectors are highlighted in bold

draws on a wide range of other sectors for its inputs, but also because such services are a vital input to almost all economic activity in this sparsely populated country. The second service sector with widely dispersed effects is financial services. Like transportation, financial services are a key input to many economic activities. However, perhaps more unexpectedly, the latter services constitute a sector that uses inputs from many other sectors.

As regards the manufacturing sectors identified as key sectors, those with widely dispersed effects—-both forward and backward—draw on raw material inputs from 
Table 6 Key sector analysis in terms of output, weighted by sector size

\begin{tabular}{|c|c|c|c|c|}
\hline Sector & $\begin{array}{l}\text { Backward } \\
\text { multiplier }\end{array}$ & $\begin{array}{l}\text { Backward } \\
\text { coefficient } \\
\text { of variation }\end{array}$ & $\begin{array}{l}\text { Forward } \\
\text { multiplier }\end{array}$ & $\begin{array}{l}\text { Forward } \\
\text { coefficient } \\
\text { of variation }\end{array}$ \\
\hline Commercial agriculture: Cereal crops & -0.0779 & -1.9610 & 0.1613 & 0.6902 \\
\hline Commercial agriculture: Other crops & 0.2195 & 2.0492 & 0.2734 & 0.6726 \\
\hline Commercial agriculture: Animal products & 0.3853 & 2.0328 & 0.5832 & 0.7113 \\
\hline Traditional agriculture & 0.6389 & 2.2449 & 0.4330 & 1.3379 \\
\hline Fishing & 1.4230 & 1.7865 & 0.9525 & 1.1278 \\
\hline Mining ${ }^{*}$ & 5.3910 & 1.8762 & 2.5952 & 1.5683 \\
\hline Meat processing & 0.9256 & 1.4983 & 0.1429 & 3.5210 \\
\hline Fish processing & 1.3446 & 1.6925 & 0.3853 & 2.2398 \\
\hline Grain milling & 0.3535 & 1.7199 & 0.2783 & 0.8580 \\
\hline Manufacture of beverages and other food processing ${ }^{*}$ & 3.1360 & 1.8945 & 1.5432 & 1.5595 \\
\hline Manufacture of textiles & 0.4927 & 2.2032 & 0.6717 & 0.6519 \\
\hline Manufacture of wood products and furniture & -0.0673 & -1.8366 & 0.4719 & 0.2961 \\
\hline Manufacture of paper, printing and publishing & -0.5111 & -2.0141 & 0.7941 & 0.6106 \\
\hline Manufacture of chemicals, rubber and plastic & -0.6374 & -2.0864 & 1.3392 & 0.5429 \\
\hline Manufacture of other non-metallic mineral products & -0.2109 & -1.5932 & 0.2461 & 1.2574 \\
\hline Manufacture of basic metals & 0.8858 & 1.4173 & 0.2048 & 2.3811 \\
\hline Manufacture of fabricated metal products and machinery & 0.0910 & 1.8405 & 1.9085 & 0.3600 \\
\hline Electricity & 0.0459 & 2.4425 & 0.8567 & 0.2503 \\
\hline Water & 0.2020 & 2.2744 & 0.4332 & 0.4780 \\
\hline Construction & 3.9418 & 1.3194 & 0.6655 & 3.0845 \\
\hline Trade and repairs & 0.0823 & 0.8329 & 0.4104 & 0.2207 \\
\hline Hotels and restaurants & 0.2296 & 1.6221 & 0.5556 & 1.1606 \\
\hline Transport & -0.3152 & -1.6273 & 2.2309 & 0.3593 \\
\hline Communication & 0.3741 & 2.1056 & 1.5293 & 0.2501 \\
\hline Finance and insurance & 0.5182 & 1.7103 & 1.6564 & 0.2856 \\
\hline Market real estate and business services & -0.1008 & -2.0601 & 3.5852 & 0.2327 \\
\hline Other private social services & 1.4711 & 1.5964 & 0.6918 & 1.3642 \\
\hline Government services ${ }^{*}$ & 6.2754 & 2.0394 & 3.6344 & 1.4282 \\
\hline
\end{tabular}

${ }^{*}$ Key sectors are highlighted in bold

the domestic economy. The goods produced are then used both as intermediate inputs and as consumer goods.

Key manufacturing sectors with less widely dispersed backward effects are those that sell their products to a broad range of other sectors-hence the widely dispersed forward effects-but whose main input from the domestic economy is the use of transportation and retail services to distribute their products. Sectors with widely dispersed backward effects but with limited or no forward effects are mostly those that draw widely on domestic inputs but sell mainly to export markets or to tourists vis- 
Table 7 Key sector analysis in terms of labor income, weighted by sector size

\begin{tabular}{|c|c|c|c|c|}
\hline Sector & $\begin{array}{l}\text { Backward } \\
\text { multiplier }\end{array}$ & $\begin{array}{l}\text { Backward } \\
\text { coefficient } \\
\text { of variation }\end{array}$ & $\begin{array}{l}\text { Forward } \\
\text { multiplier }\end{array}$ & $\begin{array}{l}\text { Forward } \\
\text { coefficient } \\
\text { of variation }\end{array}$ \\
\hline Commercial agriculture: Cereal crops & -0.0402 & 0.9876 & 0.0121 & 0.9021 \\
\hline Commercial agriculture: Other crops & 0.1364 & 0.9817 & 0.0952 & 1.2346 \\
\hline Commercial agriculture: Animal products & 0.1747 & 0.8857 & 0.2210 & 0.9498 \\
\hline Traditional agriculture* & 1.8780 & 1.6357 & 1.2677 & 1.6503 \\
\hline Fishing & 1.4964 & 1.2699 & 0.9886 & 1.3595 \\
\hline Mining ${ }^{*}$ & 3.9025 & 1.1247 & 2.1179 & 1.1102 \\
\hline Meat processing & 0.4013 & 0.6670 & 0.0191 & 1.1634 \\
\hline Fish processing & 1.1427 & 0.9518 & 0.2151 & 1.6452 \\
\hline Grain milling & 0.1757 & 0.8256 & 0.0612 & 1.1881 \\
\hline Manufacture of beverages and other food processing & 1.6830 & 0.8026 & 0.6192 & 0.6165 \\
\hline Manufacture of textiles & 0.2661 & 0.9134 & 0.2509 & 0.7805 \\
\hline Manufacture of wood products and furniture & -0.0553 & 0.9306 & 0.1244 & 0.9100 \\
\hline Manufacture of paper, printing and publishing & -0.4842 & 1.0902 & 0.1585 & 0.8848 \\
\hline Manufacture of chemicals, rubber and plastic & -0.3969 & 0.9269 & 0.3874 & 0.4969 \\
\hline $\begin{array}{l}\text { Manufacture of other non-metallic } \\
\text { mineral products }\end{array}$ & -0.1561 & 0.7876 & 0.0427 & 1.1775 \\
\hline Manufacture of basic metals & 0.5913 & 0.7827 & 0.0886 & 1.5769 \\
\hline Manufacture of fabricated metal products and machinery & 0.0688 & 1.0414 & 1.1153 & 0.4787 \\
\hline Electricity & 0.0431 & 1.4891 & 0.5741 & 1.0177 \\
\hline Water & 0.1623 & 1.3372 & 0.2354 & 1.2485 \\
\hline Construction & 2.1575 & 0.6208 & 0.2059 & 1.0943 \\
\hline Trade and repairs & 0.1687 & 1.3051 & 2.5012 & 1.3309 \\
\hline Hotels and restaurants & 0.1340 & 0.9159 & 0.2688 & 1.2105 \\
\hline Transport & -0.2613 & 1.0728 & 2.4608 & 0.7977 \\
\hline Communication & 0.3037 & 1.2245 & 1.4423 & 0.8795 \\
\hline Finance and insurance & 0.2750 & 0.7140 & 0.9858 & 0.8630 \\
\hline Market real estate and business services & -0.0523 & 0.9368 & 5.2666 & 0.7911 \\
\hline Other private social services & 2.0543 & 1.2998 & 0.9526 & 1.4757 \\
\hline Government services ${ }^{*}$ & 13.4203 & 1.5479 & 8.1868 & 1.6083 \\
\hline
\end{tabular}

* Key sectors are highlighted in bold

iting Namibia. Thus, transport and communications, identified as a sector for policy support, is indeed a key sector, according to our analysis.

Manufacturing has also been identified for policy support. Our analysis indicates that there is scope for more selectivity and targeting of individual manufacturing sectors rather than the entire range of manufacturing activities.

The special role given to mineral processing in policy documents is, however, not supported by our analysis. On the other hand, traditional agriculture, which comes 
Table 8 Key sector analysis in terms of employment, weighted by sector size

\begin{tabular}{|c|c|c|c|c|}
\hline Sector & $\begin{array}{l}\text { Backward } \\
\text { multiplier }\end{array}$ & $\begin{array}{l}\text { Backward } \\
\text { coefficient } \\
\text { of variation }\end{array}$ & $\begin{array}{l}\text { Forward } \\
\text { multiplier }\end{array}$ & $\begin{array}{l}\text { Forward } \\
\text { coefficient } \\
\text { of variation }\end{array}$ \\
\hline Commercial agriculture: Cereal crops & -0.4037 & 1.4408 & 0.2490 & 1.5707 \\
\hline Commercial agriculture: Other crops & 1.1289 & 1.5084 & 0.8860 & 1.6132 \\
\hline Commercial agriculture: Animal products ${ }^{*}$ & 2.0290 & 1.4688 & 2.3287 & 1.5568 \\
\hline Traditional agriculture ${ }^{*}$ & 3.6345 & 1.4939 & 2.0048 & 1.6718 \\
\hline Fishing & 1.4276 & 1.0451 & 0.6058 & 1.4909 \\
\hline Mining & 2.3803 & 0.7048 & 0.8534 & 0.6628 \\
\hline Meat processing & 2.1122 & 1.2449 & 0.0275 & 1.1028 \\
\hline Fish processing & 0.8343 & 0.7652 & 0.0734 & 1.6427 \\
\hline Grain milling & 0.6782 & 1.1961 & 0.1073 & 1.0087 \\
\hline Manufacture of beverages and other food processing & 2.5973 & 0.7150 & 0.7865 & 0.6388 \\
\hline Manufacture of textiles & 0.3423 & 0.8062 & 0.3205 & 0.6431 \\
\hline Manufacture of wood products and furniture & -0.0719 & 0.8047 & 0.1105 & 0.6109 \\
\hline Manufacture of paper, printing and publishing & -0.3769 & 0.9439 & 0.1372 & 0.8876 \\
\hline Manufacture of chemicals, rubber and plastic & -0.5086 & 0.9526 & 0.5531 & 0.5253 \\
\hline Manufacture of other non-metallic mineral products & -0.1463 & 0.8230 & 0.0331 & 0.8374 \\
\hline Manufacture of basic metals & 0.4405 & 0.6266 & 0.0399 & 1.4031 \\
\hline Manufacture of fabricated metal products and machinery & 0.0934 & 1.0582 & 1.3645 & 0.5281 \\
\hline Electricity & 0.0353 & 1.2661 & 0.4951 & 0.7971 \\
\hline Water & 0.1543 & 1.1890 & 0.2243 & 1.0186 \\
\hline Construction & 3.6174 & 0.8577 & 0.4591 & 1.3932 \\
\hline Trade and repairs & 0.2262 & 1.3361 & 3.3318 & 1.2477 \\
\hline Hotels and restaurants & 0.3224 & 1.0394 & 0.5785 & 1.3966 \\
\hline Transport & -0.2424 & 0.8208 & 2.9932 & 0.7732 \\
\hline Communication & 0.2708 & 1.0095 & 1.6340 & 0.8519 \\
\hline Finance and insurance & 0.3569 & 0.8503 & 1.2880 & 0.8413 \\
\hline Market real estate and business services & -0.0599 & 0.8830 & 6.2758 & 0.8247 \\
\hline Other private social services & 1.5428 & 1.0144 & 0.5573 & 1.3212 \\
\hline Government services ${ }^{*}$ & 5.8493 & 1.1627 & 2.4914 & 1.5680 \\
\hline
\end{tabular}

* Key sectors are highlighted in bold

out as a key sector according to most of our analyzes, has not been identified for policy support.

A few cautionary notes are in order at this point. The Namibian economy is highly trade-dependent, and even those sectors which are identified as having stronger-thanaverage linkages to the rest of the economy may be relatively weakly linked in absolute terms. In addition to this, since the Namibian economy is fairly small, and several of the key sectors identified here are small subsets of it, many sectors consist of only a few companies. This means that the entry of a single new company or the exit of an old one could change the structure of a sector enough to shift it from one cate- 
gory in the analysis to another. It also means that if a sector were to expand rapidly, it is uncertain whether the domestic markets would be sufficient to provide the additional inputs needed, or to absorb the additional output. In practice, constraints in other sectors might create problems-especially for those sectors identified as having multiplier effects, albeit only on a few other sectors.

Nonetheless, as long as one is contemplating interventions that are either relatively limited in scope or that will unfold over extended periods of time, key sector analysis can help identify interventions that are likely to have the greatest knock-on effects in respect of other sectors in the Namibian economy. Even in an economy as tradedependent as Namibia's, for policy purposes it is useful to identify the specific sectors where interventions are likely to have the greatest overall effect on the economy. Key sector analysis can contribute to that goal.

\section{Competing Interests}

The authors declare that they have no competing interests.

Acknowledgements Financial support from Formas through its COMMONS programme, from the Jan Wallander and Tom Hedelius foundation, and from Elforsk is gratefully acknowledged. The authors are also grateful for constructive comments from two anonymous reviewers on an earlier version of this paper. The usual disclaimers apply.

\section{Appendix: Notation Used in the Paper}

A Leontief matrix of input coefficients

$A_{i j} \quad$ Spending on inputs from sector $j$ as share of sector $i$ 's overall expenditure

B Leontief inverse

$b_{i j} \quad$ Coefficient of Leontief inverse

$\bar{B} \quad$ Average multiplier

$B_{i}$. Average forward multiplier of sector $i$

$B_{i}^{N} \quad$ Normalized forward multiplier of sector $i$

$B_{i}^{\sigma}$. Forward multiplier of sector $i$, weighted by its share of overall factor income

$B_{i}^{q} \quad$ Forward multiplier of sector $i$, weighted by employment or labor income

$B_{i}^{q \sigma}$. Forward multiplier of sector $i$, weighted by employment or labor income and by share of overall factor income

$B . j \quad$ Average backward multiplier of sector $j$

$B_{. j}^{N} \quad$ Normalized backward multiplier of sector $j$

$B_{\cdot j}^{\delta} \quad$ Backward multiplier of sector $j$, weighted by its share of overall net final demand

$B_{\cdot j}^{q} \quad$ Backward multiplier of sector $j$, weighted by employment or labor income

$B_{. j}^{q \delta}$ Backward multiplier of sector $j$, weighted by employment or labor income and by share of overall net final demand

I Identity matrix

$n \quad$ Number of sectors

$V_{i}$. Forward coefficient of variation of sector $i$ 


\section{$V_{i \text {. }}^{N} \quad$ Normalized forward coefficient of variation of sector $i$ \\ $V \cdot j \quad$ Backward coefficient of variation of sector $j$ \\ $V_{. j}^{N} \quad$ Normalized backward coefficient of variation of sector $j$ \\ $X_{i} \quad$ Total revenue and expenditure of sector $i$ \\ $\mathbf{Z}$ Matrix of monetary flows in the economy \\ $Z_{i j} \quad$ Sector $i$ 's spending on inputs from sector $j$ \\ $\delta_{j} \quad$ Sector $j$ 's share of overall net final demand \\ $\sigma_{i} \quad$ Sector $i$ 's share of overall factor income}

\section{References}

1. Augustinovics M (1970) Methods of international and intertemporal comparison of structure. In: Carter AP, Bródy A (eds) Contributions to input-output analysis. North-Holland, Amsterdam, pp 249-269

2. CBS/Central Bureau of Statistics (2009) Preliminary national accounts 2000-2008. National Planning Commission, Government of the Republic of Namibia, Windhoek

3. Chenery B, Watanabe T (1958) International comparisons of the structure of production. Econometrica 26:487-521

4. Dietzenbacher E (1997) In vindication of the Ghosh model: a reinterpretation as a price model. J Reg Sci 37:629-651

5. Ghosh A (1958) Input-output approach in an allocation system. Economica 25:58-64

6. Hewings GJD (1982) The empirical identification of key sectors in an economy: a regional perspective. Dev Econ 20:173-195

7. Hirschman A (1958) The strategy of economic development. Yale University Press, New Haven

8. Lange GM, Schade K (2008) A social accounting matrix for Namibia, 2004: a tool for analyzing economic growth, income distribution and poverty. NEPRU Working Paper 112. Namibian Economic Policy Research Unit, Windhoek

9. Laumas PS (1975) Key sectors in some underdeveloped countries. Kyklos 28:62-79

10. Laumas PS (1976) The weighting problem in testing the linkage hypothesis. Q J Econ 90:308-312

11. Laumas PS (1976) Key sectors in some underdeveloped countries: a reply. Kyklos 29:767-769

12. Lenzen M (2003) Environmentally important paths, linkages and key sectors in the Australian economy. Struct Chang Econ Dyn 14:1-34

13. Leontief W (1941) The structure of the American economy, 1919-1924: an empirical application of equilibrium analysis. Harvard University Press, Cambridge

14. McGilvray J (1977) Linkages, key sectors and development strategy. In: Leontief W (ed) Structure, system and economic policy. Cambridge University Press, Cambridge, pp 49-56

15. Ministry of Labour (2006) Labour force survey 2004. Ministry of Labour, Government of the Republic of Namibia, Windhoek

16. Nørregaard Rasmussen P (1956) Studies in inter-sectoral relations. Einar Harks, Copenhagen

17. NPC/National Planning Commission (2008) A review of poverty and inequality in Namibia. Government of the Republic of Namibia, Windhoek

18. Oosterhaven J (1988) On the plausibility of the supply-driven input-output model. J Reg Sci 28:203217

19. Oosterhaven J (1996) Leontief versus Ghoshian price and quantity models. South Econ J 62:750-759

20. Oosterhaven J (2012) Adding supply-driven consumption makes the Ghosh model even more implausible. Econ Syst Res 24:101-111

21. Rueda-Cantuche JM, Neuwahl F, Delgado L (2009) The adjustment capacity of the European economy examined with an input-output based key sector analysis: towards a review of the European Single Market. Cuaderno 01/09, Cuadernos de Trabajo de SHAIO Serie 1. Sociedad Hispanoamericana de Análisis Input-Output, Oviedo

22. United Nations (1999) Handbook of input-output table compilation and analysis. Studies in methods: handbook of national accounting, series F, vol 74. United Nations, New York 